Published by Faculty of Islamic Civilization Studies, KUIS

\title{
ANALISIS PERKEMBANGAN PENULISAN TAFSIR MAUDU'I DI MALAYSIA
}

Sahlawati Abu Bakar', Haziyah Hussin², \& Wan Nasyrudin Wan Abdullah ${ }^{2}$

${ }^{1}$ Faculty of Islamic Civilization Studies, Kolej Universiti Islam Antarabangsa Selangor (KUIS), 43000, Kajang, Malaysia.

${ }^{2}$ Faculty of Islamic Studies, Universiti Kebangsaan Malaysia, Selangor, Malaysia.

Corresponding Author: Sahlawati Abu Bakar. Department of Al-Quran and al-Sunnah, Faculty of Islamic Civilization Studies, Kolej Universiti Islam Antarabangsa Selangor (KUIS), 43000, Kajang, Malaysia. Tel: (+60) 0196015308. Email: sahlawati@kuis.edu.my

\begin{abstract}
ABSTRAK
Kajian mengenai penulisan tafsir di Malaysia dan perkembangannya telah dilakukan oleh pengkaji tafsir di Malaysia. Namun kajian mengenai penulisan tafsir mawdu'i secara khusus kurang dijalankan. Kajian ini bertujuan untuk mengemukakan perkembangan tafsir mawdu'i di Malaysia bermula pada tahun 1940an sehingga awal abad ke-20. Metode yang digunakan untuk mengkaji penulisan karya-karya tafsir mawdu'i di Malaysia adalah kualitatif dengan menggunakan kaedah analisis kandungan sebagai reka bentuk penyelidikan. Sorotan literatur dilakukan bagi mengumpulkan data berkenaan karya-karya tafsir mawdu'i. Hasil kajian mendapati corak pertafsiran al-Quran di Malaysia bermula dengan terjemahan karya-karya asli tafsir. Kemudian penulisan tafsir dibuat secara menyeluruh dan corak tafsir yang dominan ialah tafsir tahlili dan mawdu'i. Penulisan tafsir mawdu'i menunjukkan perkembangan yang besar pada abad ke-20 dan penulisan berdasarkan topik menjadi pilihan utama penulis tafsir mawdu'i di Malaysia selain lafaz dan surah. Di antara topik-topik yang dikaji ialah kisah Nabi, akidah, ekonomi, kekeluargaan dan ibadah. Justeru, kajian ini menunjukkan perkembangan yang signifikan dalam penulisan tafsir mawdu'i di Malaysia seterusnya menggambarkan keperluan masyarakat terhadap jenis tafsir ini. Kajian ini memberikan input baru kepada pengkaji tafsir di Malaysia secara umum dan tafsir mawdu'i secara khusus.
\end{abstract}

Kata kunci: Tafsir mawdu'i; Malaysia; Terjemahan; Topik; Corak pentafsiran

\section{(AN ANALYSIS OF DEVELOPMENT OF THEMATIC EXEGESIS IN MALAYSIA)}

\begin{abstract}
Various studies have been done in Malaysia on exegesis and its development. But less study was conducted on thematic exegesis. The study aimed to present the development of thematic exegesis in Malaysia beginning in the 1940s until the early 20th century. The method used to study thematic exegesis in Malaysia was qualitative, using content analysis as research designs. The literature reviews were conducted to collect the data on thematic
\end{abstract}


exegesis. The findings showed that the pattern of Quranic tafsir in Malaysia began with translating the original works of exegetes. Then the interpretation was made comprehensively, and the predominant pattern of interpretation was tafsir al-tahlili and mawdu'i. The writing of thematic exegesis showed the great development of the 20th century. The topic-based writing became the preferred choice for the author of al-mawdu' $i$ in Malaysia besides the lafaz (metonym) and surah (chapter). Among the topics studied were the story of the Prophet, faith, economy, family, and ibadah (the act of worship). Therefore, this study showed significant developments of thematic exegesis in Malaysia, which further illustrated the society's need for this kind of exegesis. This study provided new inputs to the researchers in Malaysian on exegesis in general and thematic exegesis in particular.

Keywords: Thematic exegesis; Malaysia; Interpretation; Topic; Pattern of Quranic tafsir

\section{Pendahuluan}

Menurut Muslim (2000) tafsir mawdu'i ialah ilmu yang menangani isu-isu berdasarkan maqasid al-Quran melalui satu surah ataupun lebih. Manakala Al-Khalidi, (2012) mendefinisikan tafsir mawdu'i ialah proses pengumpulan ayat-ayat al-Quran oleh pengkaji dalam satu tema atau istilah yang sama, mentafsirkannya secara kolektif serta mengistinbat dan mengaitkannya dengan maqasid al-Quran. Tafsir mawdu'i telah melalui pelbagai peringkat pertumbuhan mengikut keperluan dan keadaan semasa. Jika disoroti sejarahnya, tafsir mawdu'i tumbuh dalam tiga peringkat (Al-Khalidi, 2012; Muslim, 2000).

Peringkat pertama ialah pada zaman Nabi SAW dan para sahabat. Tafsir mawdu'i pada zaman Nabi SAW ini masih menggunakan metode analisis perkataan dan ayat (Pakeeza \& Chishti, 2012). Kaedah pentafsiran ini lebih dikenali dengan tafsir al-Quran dengan al-Quran yang merupakan asas atau teras kepada kaedah tafsir mawdu'i. Ini menunjukkan bahawa lafaz yang sama dalam al-Quran boleh membawa pelbagai maksud jika dikumpulkan dan ditafsirkan. Menurut Al-Khalidi (2012) dan Al-Kummi \& Muhammad (1982) metode yang digunakan oleh Rasulullah SAW ini dianggap oleh sebahagian ulama sebagai asas awal pertumbuhan tafsir mawdu'i.

Para sahabat juga menggunakan kaedah yang sama dalam mentafsirkan al-Quran seperti yang dilakukan oleh Nabi SAW iaitu tafsir al-Quran dengan al-Quran. Seperti yang telah dinyatakan kaedah ini adalah asas utama dalam tafsir mawdu'i. Walaupun para sahabat memahami dan menjelaskan sebahagian besar al-Quran mereka tidak menulis atau menghimpunkan ilmu mereka dalam kitab-kitab kerana pada ketika itu tiada keperluan untuk berbuat sedemikian (Muslim, 2000). Namun demikian pada zaman ini tafsir mawdu'i tidak terlalu menonjol mungkin disebabkan oleh tumpuan utama para sahabat ketika ini ialah periwayatan hadis.

Peringkat kedua ialah pada zaman pengasingan ulum Quran kepada bidang khusus. Pada peringkat ini iaitu seawal kurun ke 9 hijrah, para ulama al-Quran menghimpunkan ayat-ayat al-Quran yang membincangkan perbahasan berkaitan ulum al-Quran dan menulis kitab-kitab yang khusus mengenai bidang tersebut (Ammar, 2004). Para tabiin terutamanya membahaskan ilmu al-Quran dalam skop yang tertentu seperti nasikh mansukh, asbab nuzul, makki madani dan sebagainya. Ilmu-ilmu al-Quran ini dibahaskan dalam aspek atau sudut tertentu yang dikumpulkan dalam satu tema. Oleh itu ianya dianggap sebagai permulaan kepada tafsir mawdu'i pada zaman ini (Al-Khalidi, 2012; Muslim, 2000). 


\section{Published by Faculty of Islamic Civilization Studies, KUIS}

Al-Quran diberikan tema-tema yang tertentu bagi memahami isi kandungannya sejajar dengan perkembangan Islam dan keperluan semasa. Peningkatan jumlah penerbitan monograf dan artikel oleh para ahli tafsir berkaitan tema-tema tertentu al-Quran semenjak 1990-an menunjukkan perkembangan yang signifikan terhadap minat para ahli tafsir kepada pentafsiran al-Quran (Pink, 2014). Kitab-kitab terdahulu juga banyak yang menggunakan metode tafsir yang hampir kepada metode tafsir mawdu'i tetapi dalam bentuk yang umum dan bukan sebagai satu metode tafsir mawdu'i yang tersendiri (Didi, 2016; Faramawi, 1977). Selain itu juga terdapat ulama tafsir yang mentafsirkan ayat al-Quran yang dikumpul berdasarkan jenis ayat yang sama seperti ayat-ayat hukum. Sebagai contoh Syeikh al-Jasas menulis kitab Ahkam al-Quran dan Ibn al-'Arabi menulis kitab Ahkam al-Quran. Kitab Nazm al-Durar fi tanasub al-Ayi wa al-Suwar oleh al-Buqa'i merupakan kitab yang bercorakkan tafsir mawdu'i kerana menggunakan kaedah mengaitkan ayat dengan tema yang sama (Al-Karim, 2003). Kitab Fi Zilal al-Quran oleh Sayyid Qutb juga dianggap sebagai kitab tafsir yang menggunakan pendekatan tematik dalam pentafsiran (Zulkifli, 2003). Ini boleh dianggap sebagai salah satu jenis tafsir mawdu'i dalam kerangka yang asas dan umum. Ini merupakan asas kepada pertumbuhan penulisan tafsir mawdu'i pada zaman moden.

Peringkat ketiga ialah pada zaman moden ketika ulama Islam menghadapi serangan pemikiran musuh-musuh Islam, maka buku-buku dan kajian-kajian khusus berkaitan isu-isu dalam al-Quran dihasilkan bagi menghadapi serangan ini. Al-Khalidi (2012) menekankan bahawa kajian-kajian al-Quran kontemporari yang hampir dengan tafsir mawdu'i adalah bermaksud kajian-kajian yang khusus berkaitan topik-topik berkaitan al-Quran dan ia adalah sama sahaja dengan kajian-kajian Islam yang lain seperti hadis, fiqah, sejarah, bahasa dan lain-lain. Oleh itu ia tidak boleh dikatakan sebagai al-tafsir al-mawdu'i yang mempunyai metode khusus dalam penafsiran. Istilah tafsir mawdu'i hanya wujud pada kurun ke 14 (Muslim, 2000). Menurut Shihab (1996) tafsir mawdu'i berdasarkan surah dipelopori oleh Syeikh Mahmud Syaltut, pada tahun 1960 seorang ulama tafsir di Universiti al-Azhar yang menulis sebuah kitab berjudul Tafsir al-Qur'an al-Karim. Manakala tafsir mawdu'i berdasarkan topik dipelopori oleh Ahmad Sayyid al-Kumiy pada tahun 1960.

Ketiga-ketiga peringkat ini merupakan asas kepada pertumbuhan awal tafsir mawdu'i. Di Malaysia pula, kedatangan Islam ke Tanah Melayu pada hujung kurun ke 9 merupakan salah satu faktor bermulanya pengajian al-Quran di Tanah Melayu. Manakala penulisan tafsir pula hanya bermula selepas kurun ke 20 melalui pengajian-pengajian di pondok dan madrasah (Haziyah \& Latifah, 2013). Kajian mengenai perkembangan tafsir telah dilakukan oleh para sarjana tafsir di Malaysia (Ahmad, Mohd, \& Muhammad, 2018; Haziyah et al., 2012; Mazlan et al., 2011; Mustaffa, 2009; Siti \& Muhd, 2017), dan sorotan literatur membuktikan terdapat perkembangan yang pesat dalam penulisan tafsir di Malaysia. Corak penulisan tafsir di Malaysia terbahagi kepada beberapa jenis iaitu tahlili (menyeluruh), ijmali (ringkas) dan mawdu'i. Kedudukan tafsir mawdu'i dalam penulisan tafsir berada di kedudukan kedua selepas tafsir tahlili yang menjadi pilihan utama para penulis tafsir di Malaysia. Kecenderungan penulisan tafsir di Malaysia lebih tertumpu kepada jenis tahlili namun tafsir mawdu'i juga menjadi pilihan penulis tafsir.

Kajian ini menggunakan rekabentuk kualitatif dengan menggunakan kaedah analisis kandungan sebagai metode analisis data. Metode yang digunakan bagi mendapatkan data ialah melalui sorotan literatur kajian-kajian lepas berkaitan penulisan karya-karya tafsir secara umum di Malaysia. Berdasarkan literatur tafsir secara umum, maklumat mengenai penulisan tafsir mawdu'i secara khusus diperolehi.

Kajian-kajian lepas lebih tertumpu kepada perkembangan tafsir di Malaysia dalam beberapa ciri seperti tafsir yang lengkap ditulis 30 juzuk, tafsir surah-surah pilihan dan terjemahan kitab-kitab tafsir terkenal. Oleh itu, tujuan artikel ini adalah membincangkan 
mengenai perkembangan tafsir mawdu'i di Malaysia bermula dengan perkembangan tafsir di Malaysia secara umum dan tafsir mawdu'i secara khusus. Kajian juga membincangkan mengenai jenis-jenis karya tafsir mawdu'i yang ditulis di Malaysia.

\section{Perkembangan Tafsir di Malaysia}

Kemunculan tafsir mawdu'i di Malaysia boleh disoroti bermula daripada permulaan kedatangan tafsir secara umum di Malaysia. Kajian mengenai perkembangan tafsir dan corak penulisan tafsir di Malaysia telah dilakukan seawal tahun 1992 sehinggalah tahun 2018. Di Malaysia tafsir al-Quran bermula daripada pembelajaran al-Quran di pondokpondok dan masjid (Haziyah \& Latifah, 2013). Kegiatan tafsir al-Quran pada peringkat awal adalah secara lisan dan tidak bertulis dan aktiviti penulisan tafsir hanya bermula sekitar kurun ke 16. Karya tafsir pertama yang mula sekali ditulis menurut catatan P. Riddell (1989) ialah Tarjuman al-Mustafid oleh 'Abd Rauf al-Singkili. Sebelum karya ini Peter G. Ridell juga menemui satu manuskrip tafsir al-Quran daripada koleksi perpustakaan Universiti Cambridge. Manuskrip tafsir surah al-Kahfi ini dimiliki oleh seorang Belanda Arabist Erpenius. Selepas kitab Tarjuman al-Mustafid kitab tafsir berbahasa Arab yang dihasilkan oleh ulama Melayu ialah Marah Labid oleh Muhammad Nawawi al-Jawi (P. G. Riddell, 2014).

Penulisan tafsir di Malaysia bermula seawal kurun ke 16 dipelopori oleh seorang ulama dari Terengganu iaitu Sheikh Abdul Malik Abdullah yang dikenali sebagai Tok Pulau Manis. Ketika berada di Acheh Tok Pulau Manis menyalin semula kitab Tafsir al-Baydawi yang telah diterjemahkan ke dalam bahasa Melayu oleh Abdul Rauf al-Singkili. Sehinggalah pada kurun ke 20 muncul lagi beberapa orang tokoh ulama tafsir di Malaysia seperti Tok Kenali, Tuan Haji Muhammad Said, Maulana Abdullah Nuh, Muhammad Idris al-Marbawi, Dato' Haji Muhammad Noor Ibrahim, Sheikh Abdullah Basmeih dan lain-lain (Haziyah et al., 2012).

Kajian mengenai perkembangan tafsir di Malaysia dipelopori oleh Ismail (1995). Dalam kajian tersebut beliau membahagikan penulisan kitab tafsir di Malaysia kepada dua bahagian iaitu bahagian pertama penulisan kitab tafsir lengkap 30 juzuk, tafsir surah-surah pilihan dan terjemahan. Contoh kitab tafsir bahagian pertama ini ialah seperti Tafsir Nur alIhsan oleh Tuan Haji Muhammad Said Omar, Tafsir Pimpinan al-Rahman oleh Sheikh Abdullah Basmeih dan kitab Khulasah al-Quran oleh Maulana Abdullah Awang Nuh. Kitab Ramuan Rapi dari Surah al-Kahfi oleh Tuan Haji Muhammad Noor Ibrahim dan Tafsir Surah Yusuf oleh Muhammad Idris al-Marbawi pula merupakan contoh tafsir surah-surah pilihan.

Bahagian kedua penulisan tafsir ialah dalam bentuk terjemahan kitab-kitab tafsir alQuran seperti terjemahan Tafsir al-Jalalayn oleh Sheikh Uthman Jalaluddin, Intisari alQuran terjemahan oleh Sheikh Abdullah Basmeih. Selain itu terjemahan surah Yaasin daripada kitab tafsir al-Syawkani karya al-Marbawi Menurut Haziyah \& Latifah (2013), kitab-kitab tafsir terjemahan lebih dahulu dihasilkan berbanding kitab tafsir tahlili. Namun pada pada tahun 1930-an kitab tafsir tahlili dan ijmali semakin bertambah dan pada masa ini jugalah Tafsir Nurul Ihsan lengkap 30 juzuk dihasilkan. Carta 1 di bawah menunjukkan jumlah penerbitan kitab-kitab tafsir di Malaysia berbanding tahun. 


\section{Published by Faculty of Islamic Civilization Studies, KUIS}

Carta 1. Jumlah penerbitan kitab-kitab tafsir di Malaysia mengikut tahun

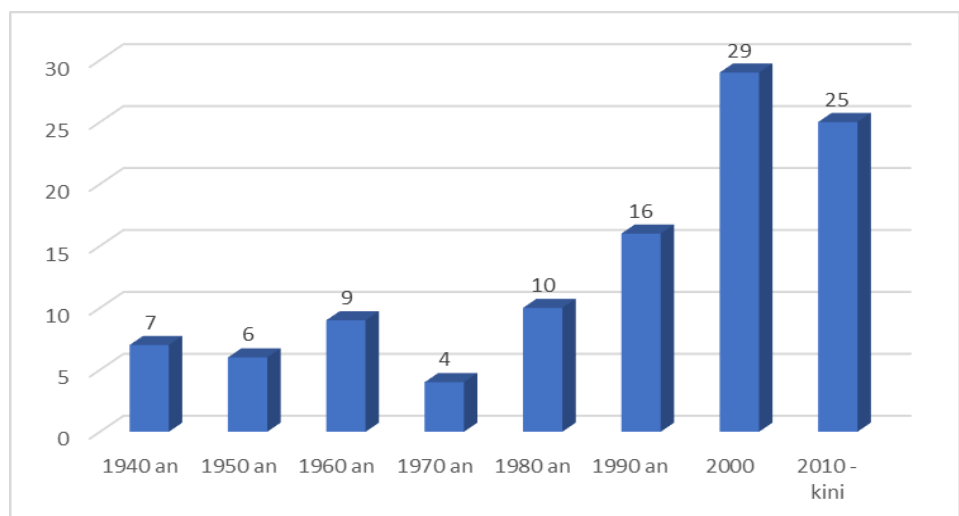

Sumber: Mustaffa, Fauzi, \& Faisal (2009); Haziyah et al. (2012); Mazlan et al. (2011); Siti \& Muhd (2017); Ahmad, Mohd, \& Muhammad (2018)

Berdasarkan carta hasil kajian menunjukkan terdapat 106 kitab-kitab tafsir yang dihasilkan bermula daripada tahun 19400-an sehingga tahun 2018. Bermula pada tahun 1940-an sehingga 1980-an terdapat sejumlah 36 buah penerbitan dan pada tahun-tahun seterusnya menunjukkan peningkatan jumlah penerbitan. Terdapat peningkatan yang tinggi dalam penghasilan kitab-kitab tafsir pada tahun 1990-an dan 2000 iaitu masing-masing sebanyak 16 buah kitab dan 29 buah kitab

Pada tahun 2012, Haziyah telah menyenaraikan sebanyak 39 karya penulisan tafsir bermula pada tahun 1920-an sehingga tahun 1990-an (Haziyah et al., 2012). Lima tahun selepas itu (Siti \& Muhd, 2017) membuat senarai karya tafsir yang tertumpu kepada penerbitan karya tafsir di Malaysia abad ke 21 bermula tahun 2001-2015. Beliau menyenaraikan sebanyak 66 buah karya. Kajian ini membuat analisis terhadap senarai itu dan menyaring beberapa karya dan hanya mengambil karya asli penulis Malaysia sahaja. Melalui senarai karya-karya tafsir tersebut kajian membuat pembahagian terhadap corak karya pentafsiran pula. Carta 2 di bawah menunjukkan corak karya pentafsiran di Malaysia.

\section{Carta 2. Corak pentafsiran di Malaysia berbanding tahun}

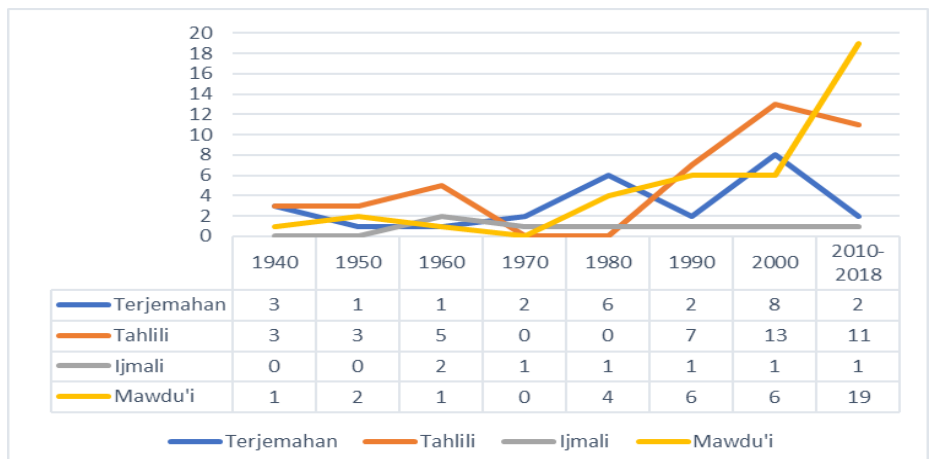

Sumber: Mustaffa, Fauzi, \& Faisal (2009); Haziyah et al. (2012); Mazlan et al. (2011); Siti \& Muhd (2017); Ahmad, Mohd, \& Muhammad (2018) 
Berdasarkan carta 2, terjemahan kitab-kitab tafsir tahun 1980-an dan 2000 banyak dihasilkan namun jumlahnya semakin berkurangan. Bagi jenis tafsir tahlili pula jumlahnya semakin meningkat dari tahun ke tahun terutama pada tahun 1990-an, 2000 dan 2010 sehingga kini. Pada tahun 2000 hingga tahun 2009 terdapat 13 buah buku tafsir jenis tahlili diterbitkan manakala pada tahun 2010 sehingga kini 11 buah buku tafsir tahlili diterbitkan. Buku tafsir jenis ijmali tidak berapa dipilih oleh penulis tafsir di Malaysia kerana jumlahnya hanya sebanyak dua buah atau sebuah sahaja pada setiap sepuluh tahun. Jenis mawdu'i menunjukkan peningkatan ketara dan semakin dipilih oleh pentafsir al-Quran pada kurun terkini. Pada tahun 2000 sehingga 2009 terdapat enam buah buku dan kemudian pada tahun 2010 sehingga kini bertambah 19 buah buku lagi.

\section{Perkembangan Tafsir Mawdu'i di Malaysia}

Tafsir mawdu'i dianggap sebagai tafsir moden oleh sebilangan ulama tafsir kontemporari. Ali (2018) mengkategorikan tafsir moden kepada beberapa jenis seperti tafsir tekstual, tafsir kontekstual, tafsir feminis dan tafsir mawdu'i. Tafsir mawdu'i merupakan tafsir moden kerana ia menggunakan pendekatan yang lebih terfokus kepada tema tertentu dalam menyelesaikan isu semasa bercorakkan ilmiah, sufi, politik dan sebagainya (Yamani, 2015). Sebahagian ulama berpendapat tafsir mawdui merupakan jenis tafsir bi al-ma'thur kerana ianya merupakan tafsir al-Quran bi al-Quran (Al-Khalidi, 2012) namun apabila ianya ditambah dengan pendapat dan pandangan pentafsir ianya boleh dikategorikan sebagai bi al$r a$ 'yi yang berdasarkan kepada ijtihad dan pemahaman akal terutamanya apabila munculnya aliran-aliran akidah dan fekah serta kepelbagaian aliran falsafah dalam masyarakat Islam (Zainal Abidin \& Ibrahim, 2018).

Menurut Wielandt (2008), pada akhir kurun ke 20 penerbitan tafsir secara globalnya yang mengklasifikasikan ayat-ayat utama teks al-Quran berdasarkan subjek utama dan ayat-ayat yang berkaitan dengan subjek yang sama menunjukkan peningkatan jumlah. Pentafsiran mawdu'i boleh berbeza berdasarkan kepelbagaian penulis karya.Selain itu, tafsir mawdu'i juga berbeza dengan tasfir yang lain dari aspek teknikal iaitu proses pengumpulan ayat dan pemberian tema (Al-Khalidi, 2012; Al-Kummi \& Muhammad, 1982). Walaupun pada hakikatnya sebilangan pengkaji mengkategorikan kitab-kitab tafsir sebagai mawdu'i namun pendekatan tafsir mawdu'i yang diaplikasikan masih perlu diteliti dengan lebih mendalam. Ini berkemungkinan kitab tafsir tersebut merupakan tafsiran dari perspektif al-Quran bukan tafsir mawdui secara pasti.

Berdasarkan tahun penerbitan, karya tafsir mawdu'i di Malaysia dikenalpasti dihasilkan bermula pada tahun 1940an dengan satu karya sahaja. Begitu juga pada tahun 1950 an dan 1980 an. Tiada karya dikenalpasti sepanjang tahun 1960-an dan 1970-an. Pada tahun-tahun seterusnya terdapat peningkatan dalam penghasilan karya. Selepas itu pada tahun-tahun berikutnya terdapat peningkatan yang berterusan terutamanya pada tahun 2010 sehingga kini dengan pertambahan sebanyak 42 peratus iaitu sebanyak 19 penerbitan.

Jadual 1. Senarai karya Tafsir Mawdu'i di Malaysia

\begin{tabular}{|c|c|c|c|c|}
\hline Bil & Tahun & Nama Kitab & Nama Pengarang & Jenis \\
\hline 1. & 1947 & $\begin{array}{l}\text { Falsafah Berumahtangga (Tafsir } \\
\text { Surah al-Mujadalah) }\end{array}$ & $\begin{array}{l}\text { Nik Muhammad Salleh Wan } \\
\text { Musa }\end{array}$ & Mawdu'i (Surah) \\
\hline 2. & 1950 & Tafsir Surah al-Ikhlas & $\begin{array}{l}\text { Abdullah al-Qari Haji } \\
\text { Salleh }\end{array}$ & Mawdu'i (Surah) \\
\hline 3. & 1958 & Falsafah Kiamat dari surah al-Naba' & Yusuf Zaky Yacob & Mawdu'i (Surah) \\
\hline 4. & 1960 & Tahukah Kamu: Tentera Gajah? & $\begin{array}{l}\text { Abdullah al-Qari Haji } \\
\text { Salleh }\end{array}$ & Mawdu’i (Surah) \\
\hline 5. & 1985 & Revolusi Menjaga Masa Menurut al- & Abdullah al-Qari Haji & Mawdu'i (Topik) \\
\hline
\end{tabular}




\section{Published by Faculty of Islamic Civilization Studies, KUIS}

$\begin{array}{lr}\text { 6. } & 1985 \\ \text { 7. } & 1985 \\ \text { 8. } & 1989\end{array}$

9. $\quad 1990$

10. 1993

11. 1995

12. 1996

13. 1996

14. 1997

15. 2003

16. 2003

17. 2005

18. 2006

19. 2007

20. 2008

21. 2008

22. 2010

23. 2010

24. 2011

25. 2012

26. 2012

27. 2013

28. 2013

29. 2014

30. 2014

31. 2014

32. 2014
Qur'an

Do'a Para Nabi,Wali,Orang 'Alim Dan Orang Shaalih Dalam Al-Qur'an Arah Dan Tujuan Hidup Di Dunia Menurut Al-Qur'an Ayat-ayat Dialog Nabi-Nabi dalam al-Quran

Koleksi Bismillah dan Intisarinya

Ayat-ayat Cabaran dan Bimbingan Allah Merajai Kerajaan Langit dan Bumi Menurut al-Qur'an

Bahaya Syirik menurut al-Qur'an

Samudera al-Fatihah Penyuluh

Hidup Mukmin

Mencari Hidayah Al-Quran, Perintis Intisari al-Quran/

Perintis Intisari al-Quran: Kutipan

Suci Resam Uthmani

Tafsir Ayat-Ayat Ahkam

Surah al-Falaq: Waspada Kejahatan Makhluk

Mengenali Allah Melalui Ayat-Ayat Suci Al-Quran

Ekonomi Dalam Perspektif al-Quran dan Al-Sunnah

Sumbangan Islam Kepada Sektor

Pertanian Negara Menurut al-Quran dan Al-Sunnah

Rahsia Kejadian Tubuh dan Organ

Manusia Menurut al-Quran dan Sains

Surah Tabaarak : Pencegah Seksaan

Kubur

Surah Luqman Mendidik Anak

Cemerlang

Al-Quran Berbicara Tentang Takwa

Fizilal Rahman Di Bawah Naungan

Maha Penyayang

Tidurnya Mereka 309 Tahun

Ashabul Kahfi

Tafsir Ayat-Ayat Ramadan

Ayat-Ayat Syaitan, Membongkar

Rahsia Jin, Syaitan Dan Iblis Dalam

Al-Quran

Ajarkan Wanitamu Surah Al-Nur

Tafsir Mawdu'i, Surah-Surah Pilihan

Al-Tafsir Al-Maudu'i Lafaz Al-

Nafar Dalam Al-Quran

Tafsir Maudhu'iy Jilid 1: Akidah

Tafsir Maudhu'iy Jilid 2: Ibadah

Tafsir Maudhu'iy Jilid 3:
Salleh

Abdullah al-Qari Haji

Salleh

Abdullah al-Qari Haji

Salleh

Disusun oleh Unit Quran

Sunnah dan Kitab, Pusat

Penyelidikan Islam, Jabatan

Perdana Menteri. Disemak

oleh Dato' Hj Ismail Yusoff

(Bekas Mufti Kelantan)

Abdullah al-Qari Haji

Salleh

Abdullah al-Qari Haji

Salleh

Abdullah al-Qari Haji

Salleh

Abdullah ar-Rahmat

Abdullah al-Qari Haji

Salleh

Zulkifli Hj. Mohd Yusoff

Arifin Omar

Mohd Rashad Shamsuddin

Mohd Radzi Othman dan Ghafarullah Huddin Din

Abdullah al-Qari Haji

Salleh

Abdul Latief Ghazali

Abdullah al-Qari Haji

Salleh

Abdul Rashid Ahmad

Raja Ahmad Mukhlis bin

Raja Jamaludin

Mohd. Rumaizuddin

Ghazali

Abdul Fatah Zakaria

Heizal Hezry Omar

Abdullah Bukhari Abdul

Rahim

Nafisah Tahir \& Kamal

Ashaari

Zulkifli Mohd Yusoff \&

Ahmad Hasan Farhat

Abur Hamdi Usman \&

Mazlan Ibrahim

Mohd Nizam Sahad

Mohammad Zaini Yahya et al

Wan Nordin Wan Abdullah
Mawdu'i (Topik)

Mawdu'i (Surah)

Mawdu’i (Topik)

Mawdu'i (Topik)

Mawdu'i (Topik)

Mawdu'i (Topik)

Mawdu'i (Topik)

Mawdu'i (Topik)

Mawdu'i

(Surah)

Mawdu'i (Topik)

Mawdu'i (Topik)

Mawdu'i (Topik)

Mawdu’i (Topik)

Mawdu'i (Topik)

Mawdu'i (Surah)

Mawdu’i (Surah)

Mawdu'i (topik)

Mawdu'i (Topik)

Mawdu'i (Topik)

Mawdu'i (Topik)

Tafsir Mawdu'i

(Topik)

Mawdu'i (Surah)

Mawdu'i (Surah)

Mawdu'i

(Perkataan)

Mawdu'i (Topik)

Mawdu'i (Topik)

Mawdu'i (Topik) 


\begin{tabular}{|c|c|c|c|c|}
\hline 33. & 2014 & $\begin{array}{l}\text { Kekeluargaan } \\
\text { Tafsir Maudhu'iy Jilid 4: Ekonomi } \\
\text { dan Kewangan }\end{array}$ & $\begin{array}{l}\text { et al } \\
\text { Wan Nasyrudin Wan } \\
\text { Abdullah et al }\end{array}$ & Mawdu'i (Topik) \\
\hline 34. & 2014 & Tafsir Maudhu'iy Jilid 5: Akhlak & Rijaluddin Yahya et al & Mawdu'i (Topik) \\
\hline 35. & 2014 & $\begin{array}{l}\text { Tafsir Maudhu'iy Jilid 6: Politik dan } \\
\text { Urus Tadbir }\end{array}$ & $\begin{array}{l}\text { Arieff Salleh Rosman \& } \\
\text { Yahaya Jusoh }\end{array}$ & Mawdu'i (Topik) \\
\hline 36. & 2014 & $\begin{array}{l}\text { Tafsir Maudhu'iy Jilid 7: Hudud, } \\
\text { Qisas dan Ta'zir }\end{array}$ & Lukman Abdul Mutalib et al & Mawdu'i (Topik) \\
\hline 37. & 2014 & $\begin{array}{l}\text { Tafsir Maudhu'iy Jilid 8: Ilmu dan } \\
\text { Tamadun }\end{array}$ & Suhaila Abdullah et al & Mawdu'i (Topik) \\
\hline 38. & 2014 & $\begin{array}{l}\text { Tafsir Maudhu'iy Jilid 9: Masyarakat } \\
\text { dan Pembangunan Sosial }\end{array}$ & $\begin{array}{l}\text { Muammar Ghadafi } \\
\text { Hanafiah et al }\end{array}$ & Mawdu'i (Topik) \\
\hline 39. & 2014 & $\begin{array}{l}\text { Tafsir Maudhu'iy Jilid 10: } \\
\text { Pemuliharaan Alam Sekitar }\end{array}$ & $\begin{array}{l}\text { Farahwahida Mohd Yusof } \\
\text { \& Mikdar Rusdi }\end{array}$ & Mawdu'i (Topik) \\
\hline 40. & 2015 & $\begin{array}{l}\text { Tafsir Mawdui: Harta Menurut } \\
\text { Perspektif Al-Quran }\end{array}$ & $\begin{array}{l}\text { Muhd Najib Abdul Kadir \& } \\
\text { Mazlan Ibrahim }\end{array}$ & Mawdu'i (Topik) \\
\hline
\end{tabular}

Natijahnya berdasarkan jadual 1 bermula seawal tahun 1947 karya tafsir mawdu'i telah mula dihasilkan oleh ulama tafsir di Malaysia. Namun jumlah karya tafsir mawdu'i masih kecil jika dibandingkan dengan jenis karya-karya tafsir yang lain. Selain kitab-kitab tafsir, penulisan tafsir di majalah juga banyak menggunakan manhaj tafsir mawdu'i (Mohd Asmadi, 2008). Hanapi (2011) telah melakukan satu kajian mengenai pola tafsir mawdu'i di Malaysia. Walaubagaimanapun kajian beliau difokuskan kepada penulisan tesis dan disertasi di peringkat Institusi Pengajian Tinggi.

Penulisan tafsir mawdu'i bermula pada tahun 1947 iaitu buku Falsafah Berumahtangga (Tafsir Surah al-Mujadalah) karya Nik Muhammad Salleh Wan Musa dan diterbitkan oleh Mustafa Press Kelantan. Buku ini membahaskan mengenai peranan wanita Islam dalam kemajuan Islam serta mewujudkan keluarga bahagia. Walau bagaimanapun buku ini tidak diterima oleh mufti daripada tiga buah negeri iaitu Johor, Pahang dan Terengganu kerana penulis buku ini dituduh zindiq dan mulhid oleh mufti Johor dan akhirnya buku ini diharamkan oleh Majlis Agama Kelantan (Mustaffa, 2009). Seterusnya pada tahun 1989 pula sebuah lagi kitab tafsir mawdu'i diterbitkan dengan judul Ayat-ayat Dialog Nabi-Nabi dalam al-Quran. Buku ini disusun oleh Unit Quran Sunnah dan Kitab, Pusat Penyelidikan Islam, Jabatan Perdana Menteri dan disemak oleh Dato' $\mathrm{Hj}$ Ismail Yusoff (Bekas Mufti Kelantan). Buku ini merupakan tafsir mawdu'i jenis topik iaitu tafsir ayat-ayat yang mengandungi dialog kisah Nabi-nabi, seperti dialog Nabi dengan Allah dan dialog Nabi dengan umatnya merangkumi 13 cerita para Nabi.

Kajian yang dilakukan oleh Ahmad Zulfiqar dkk pada tahun 2018 mengkhususkan kepada mufassir mawdu'i Malaysia iaitu Tuan Haji Abdullah Al-Qari Haji Salleh (AQHAS) (Ahmad et al., 2018). Kajian ini mendapati Tuan Haji Abdullah Al-Qari telah menghasilkan sebanyak 56 karya-karya mawdu'i. Namun pengkaji hanya mengambil karya asli penulis sahaja sebagai dapatan kajian ini. Buku tafsir mawdu'i surah yang pertama ditulis oleh Abdullah al-Qari ialah Tafsir Surah al-Ikhlas yang ditulis ketika beliau berusia 15 tahun. Selepas itu Abdullah al-Qari terus menghasilkan karya-karya tafsir mawdu'i. Jadual 1 menunjukkan Abdullah al-Qari telah menghasilkan sebanyak 11 buah buku tasfir mawdu'i. Menurut Zulkifli (2003) kajian tematik AQHAS boleh ditemui di Perpustakaan Angkatan Sayap Al-Islam (ASA), Penerbitan ASA, Tingkat 1, Bangunan Masjid Al-Sunnah/ Pusat Kajian dan Sebaran Al-Quran dan Al-Sunnah Nusantara, Desa al-Qari.

Penulisan karya-karya tafsir mawdu'i di Malaysia meningkat dari tahun ke tahun. Walaupun pada awalnya karya tafsir mawdu'i tidak ditulis dengan banyak seperti pada tahun 1940 an, 1950 an dan 1980 an iaitu sebanyak sembilan terbitan sahaja. Penulisan tafsir 


\section{Published by Faculty of Islamic Civilization Studies, KUIS}

mawdu'i selepas itu bertambah dengan ketara sekali terutamanya pada tahun 2010 sehingga kini iaitu sebanyak 19 penerbitan. Jumlah ini lebih banyak berbanding tahun-tahun sebelumnya kerana pada tahun 2014 pihak Dewan Bahasa dan Pustaka (DBP) telah menerbitkan sebanyak 10 jilid tafsir mawdu'i berdasarkan kepada tema-tema tertentu. Perkembangan penulisan tafsir mawdu'i ini jelas menunjukkan corak pentafsiran tafsir mawdu'i semakin dipilih oleh para mufassir di Malaysia.

Carta 3 di bawah menunjukkan jumlah penerbitan karya tafsir mawdu’i di Malaysia berbanding tahun.

Carta 3. Jumlah penerbitan karya Tafsir Mawdu'i berbanding tahun

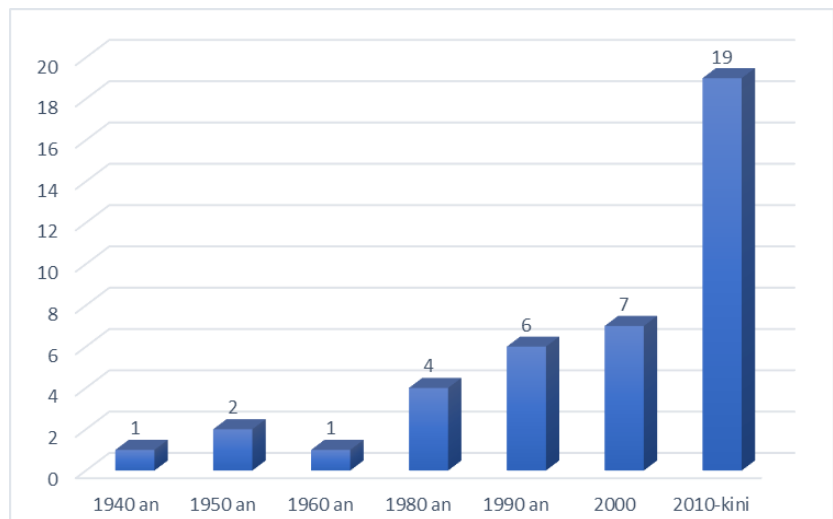

Sumber : Mustaffa, Fauzi, \& Faisal (2009); Haziyah et al. (2012); Mazlan et al. (2011); Siti \& Muhd (2017); Hadi, Latif, \& Rahman (2018)

Berdasarkan carta 3 jumlah penerbitan karya tafsir mawdu'i di Malaysia menunjukkan peningkatan pada tahun 2000 berbanding tahun-tahun sebelumnya iaitu daripada sebuah karya pada tahun 1940, 1960, empat karya pada tahun 1980, pada tahun 1990 kepada enam buah karya. Lonjakan penerbitan tafsir mawdu'i bertambah banyak pada tahun 2010 sehingga kini sebanyak 19 buah karya hasil daripada terbitan 10 buah jilid tafsir mawdu'i oleh Dewan Bahasa dan Pustaka (DBP). Seterusnya kajian mengklasifikasikan pula karya tafsir mawdu'i kepada jenis-jenisnya sama ada jenis perkataan, topik atau surah. Bilangan penerbitan berdasarkan jenis tafsir mawdu'i ditunjukan dalam carta 4 di bawah.

Carta 4. Jumlah Penulisan Tafsir Mawdu'i di Malaysia Berbanding Jenis

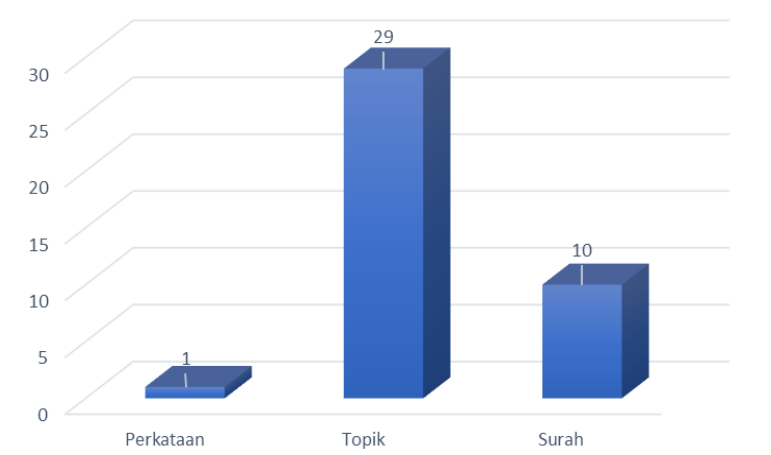

Sumber: Mustaffa, Fauzi, \& Faisal (2009); Haziyah et al. (2012); Mazlan et al. (2011); Siti \& Muhd (2017); Ahmad, Mohd, \& Muhammad (2018) 
Jika dianalisis berdasarkan jenis tafsir mawdu'i pula, penulisan tafsir mawdu'i di Malaysia boleh dibahagikan kepada tiga bahagian utama iaitu tafsir mawdu'i berdasarkan perkataan, topik dan surah (Zulkifli, 2003). Kajian mendapati tafsir mawdu'i yang dihasilkan di Malaysia lebih banyak daripada jenis tafsir mawdu'i topik berbanding jenis perkataan dan surah. Carta 4 menunjukkan karya tafsir mawdu'i jenis perkataan hanya terdapat satu sahaja iaitu Al-Tafsir Al-Maudu'i Lafaz Al-Nafar Dalam Al-Quran. Manakala jenis tafsir mawdu'i berdasarkan topik terdapat sebanyak 29 karya dan jenis tafsir mawdu'i berdasarkan surah sebanyak 10 karya. Topik-topik yang dihasilkan merangkumi isu-isu berkaitan ekonomi, pertanian, para Nabi, takwa dan sebagainya. Karya tafsir mawdu'i berdasarkan topik yang paling banyak diterbitkan ialah Tafsir Maudhu'iy terbitan Dewan Bahasa dan Pustaka. Koleksi tafsir tematik ini mempuyai 10 jilid mengikut tema-tema tertentu, seperti akidah, ibadah, kekeluargaan, ekonomi dan kewangan, akhlak, politik dan urus tadbir, hudud, qisas dan ta'zir, ilmu dan tamadun, masyarakat dan pembangunan sosial dan pemuliharaan alam sekitar. Topik-topik ini dipilih berdasarkan keperluan masyarakat Malaysia. Tema-tema yang dipilih boleh dijadikan sebagai panduan dan penyelesaian kepada permasalahan yang sedang dihadapi masyarakat secara realiti (Lilik, 2011). Manakala tafsir mawdu'i berdasarkan surah adalah kedua tertinggi selepas topik iaitu sebanyak 7 karya. Di antara surah-surah yang dipilih dan ditafsirkan secara tematik ialah surah al-Fatihah, al-Ikhlas, al-Naba', Luqman, al-Falaq, al-Mujadalah dan al-Nur kerana surah-surah ini merupakan surah-surah yang menjadi kelaziman dibaca oleh masyarakat di Malaysia (Zulkifli, 2003).

\section{Penutup}

Kajian mendapati penulisan tafsir mawdu'i di Malaysia lebih cenderung kepada mengaplikasikan pendekatan tematik dalam penulisan dan bukan penulisan metodologi tafsir mawdu'i. Hasilnya banyak karya-karya tafsir mawdu'i yang ditulis menggunakan jenis tafsir mawdu'i berdasarkan topik atau tema tertentu. Berbeza dengan ulama tafsir mawdu'i pada zaman moden yang berbahasa Arab mereka menulis kedua-dua karya tafsir mawdu'i sama ada metodologi tafsir atau aplikasi pendekatan mawdu'i. Oleh itu penulisan karya tafsir mawdu'i di Malaysia masih memerlukan kepada penelitian dari aspek metodologi tafsir mawdu'i yang digunakan dalam penulisan.

Berdasarkan perbincangan mengenai perkembangan tafsir mawdu'i di Malaysia, kajian menunjukkan penerbitan karya-karya tafsir mawdu'i semakin bertambah dan menjadi pilihan penulis tafsir di Malaysia selain tafsir tahlili. Perkembangan tafsir mawdu'i ini menunjukkan signifikan tafsir mawdu'i dalam memenuhi keperluan tasfir masyarakat Malaysia. Pertambahan bilangan karya tafsir mawdu'i dari tahun ke tahun juga membuktikan para penulis tafsir mawdu'i terutamanya tafsir mawdu'i jenis topik mempunyai kecenderungan dan minat menghasilkan karya-karya tafsir mawdu'i dalam bahasa Malaysia. Tafsir mawdu'i jenis perkataan dan surah masih kurang ditulis dan perlu kepada usaha yang lebih daripada penulis tafsir di Malaysia untuk menghasilkan karya sedemikian. Jika disoroti pada judul buku tafsir mawdui yang dihasilkan terdapat perbezaan dari aspek penamaan kitab iaitu sama ada menggunakan perkataan tafsir mawdui ataupun tidak. Justeru itu kajian mendapati masih terdapat ruang perbahasan dari aspek pendekatan dan langkah-langkah tafsir yang digunakan dalam kitab-kitab tersebut. Ini bermaksud kitab yang tidak menggunakan nama tafsir mawdu'i berkemungkinan merupakan tafsir dari perspektif al-Quran dan dikategorikan oleh pengkaji sebelum ini sebagai tafsir mawdu'i. 


\section{Published by Faculty of Islamic Civilization Studies, KUIS}

\section{Rujukan}

Ahmad, Z. S., Mohd, A. N., \& Muhammad, H. A. (2018). Ketokohan Tn. Hj. 'Abdullah Al Qari Bin Hj. Salleh (" AQHAS) sebagai tokoh mufassir tematik di Malaysia. International Journal of Islamic and Civilizational Studies (UMRAN), 05(3), 13-24.

Al-Karim, A. M. A. (2003). Al-Imam Syahid Hasan al-Banna wa manhajuhu fi Tafsir alQuran al-Karim. Jordan: Dar al-Tauzi' wa al-Nasyr al-Islamiyyah.

Al-Khalidi, S. A. (2012). Al-Tafsir al-Maudu'i bayna al-nazariyyah wa al-tatbiq. Jordan: Dar al-Nafais.

Al-Kummi, A., \& Muhammad, A. Y. (1982). Al-Tafsir al-Maudi'i li al-Quran al-Karim. Kaherah: Dar al-Nafais.

Ali, A. (2018). A brief review of classical and modern tafsir trends and the role of modern tafsir in contemporary Islamic thought. Australian Journal of Islamic Studies, 2(2), $39-52$.

Ammar, F. (2004). An analysis of historical development of tasir mawdui. Jurnal Usuluddin, 20, 89-104.

Didi, J. (2016). Mengenal lebih dekat metode tafsir maudlu'i. Diya Al-Afkar, 4(01), 19-35.

Faramawi, A. (1977). Al-Bidayah fi al-tafsir al-mawdu'i : Dirasah manhajiyah mawdu iyah. Kaherah: Maktabat Jumhuriyat Misr.

Hanapi, M. S. (2011). Pola kajian tafsir al-mawdu'iy di Malaysia. Jurnal Islam Dan Masyarakat Kontemporari, 4, 137-158.

Haziyah, H., \& Latifah, A. M. (2013). Early development of Quranic exegesis in Malaysia. International Journal of Asian Social Science, 3(8), 1732-1744.

Haziyah, H., Mazlan, I., Latifah, A. M., Kharuddin, M. A., Sabri, M., Fadlan, M. O., ... Faisal, A. S. (2012). The trend of Malay Quranic commentary writing in Malaysia in the 20th century. Journal of Applied Sciences Research, 8(8), 4343-4349.

Ismail, Y. (1995). Perkembangan penulisan dan terjemahan kitab-kitab tafsir di Malaysia. Islamiyyat, 16, 19-32.

Lilik, U. K. (2011). Studi kritis atas metode tafsir tematis al-Quran. ISLAMICA, 5(2), 354366.

Mazlan, I., Mohamad, Z. M. Z., Ahamad, A. S., Mohd, R. M. N., Mohd, N. A. K., Jaffary, A., ... Latifah, A. M. (2011). Development of Quranic exegesis in Malay Archipelago: A Special reference to Malaysia. Advances in Natural and Applied Sciences, 5(5), 452-455.

Mohd Asmadi, Y. (2008). Penulisan tafsir mawdu'i di Malaysia: Kajian terhadap artikel "Di bawah gema Al-Qur'an" oleh Yusoff Zaky Yakob dalam majalah Pengasuh edisi Februari 1975 hingga Mac 1982. University Malaya.

Muslim, M. (2000). Mabahith fi Al-Tafsir al-Mawdu'i. Damsyik: Dar al-Qalam.

Mustaffa, A. (2009). Khazanah tafsir di Malaysia. Kuala Lumpur: Akademi Pengajian Islam Universiti Malaya.

Mustaffa, A., Fauzi, D., \& Faisal, A. S. (2009). Khazanah al-Quran dan al-Hadith Nusantara. Kuala Lumpur: Akademi Pengajian Islam Universiti Malaya.

Pakeeza, S., \& Chishti, A. A. (2012). Critical study of approaches to the exegesis of the holy Qur'an. Pakistan Journal of Islamic Research, 10(4), 19-26.

Pink, J. (2014). Tafsır and Islamic intellectual history exploring the boundaries of a genre. UK: Oxford University Press.

Riddell, P. (1989). Earliest Quranic exegetic activity in the Malay speaking states. Archipel, 38(1), 107-124. https://doi.org/10.3406/arch.1989.2591.

Riddell, P. G. (2014). Variations on an exegetical theme: Tafsīr foundations in the malay world. Studia Islamika, 21(2), 259-292. https://doi.org/10.15408/sdi.v21i2.1072. 
Shihab, M. Q. (1996). Wawasan Al-Quran: Tafsir tematik atas pelbagai persoalan umat. Bandung: Pustaka Mizan.

Siti, W. M., \& Muhd, N. A. K. (2017). Corak penulisan tafsir di Malaysia abad ke-21 (20012015). Jurnal Al-Turath, 2(1), 27-36.

Wielandt, R. (2008). Exegesis of the Qur'ān: Early Modern and contemporary. In Encyclopaedia of the Qur'an (pp. 124-142).

Yamani, M. T. (2015). Memahami Al-Qur'an dengan metode tafsir maudhu'i. J-PAI, I(2), 273-292.

Zainal Abidin, S., \& Ibrahim, M. (2018). Analisis perbandingan metode hermeneutik dan tafsir bi al-ra'yi dalam penafsiran Al-Quran. Al-Irsyad: Jurnal Of Islamic And Contemporary Issues, 3(2), 43-59.

Zulkifli, M. Y. (2003). Tafsir Al-Mawdu'i: Kajian pensejarahan. Al-Bayan: Jurnal Of AlQuran \& Al-Hadith, 1, 27-41.

\section{Author's Biography}

Sahlawati Abu Bakar, seorang pensyarah di Jabatan al-Quran dan al-Sunnah, Fakulti Pengajian Peradaban Islam, Kolej Universiti Islam Antarabangsa Selangor (KUIS). Beliau sedang melanjutkan pengajian di peringkat Ijazah Kedoktoran dalam bidang Tafsir al-Quran di Pusat Kelestarian Turath Islami, Universiti Kebangsaan Malaysia.. Beliau memperolehi Ijazah Sarjana dalam bidang Al-Quran daripada pusat dan universiti yang sama dan Ijazah Sarjana Muda dalam bidang al-Quran dan al-Sunnah daripada Universiti Islam Antarabangsa Malaysia. Bidang tujahan beliau tertumpu kepada pengajian al-Quran, ulum al-Quran, tafsir al-Quran, tafsir mawdu'i dan pengajian Islam secara umum. Beliau juga banyak terlibat dengan penyelidikan dan pembinaan model sama ada sebagai Ketua Penyelidik atau pun sebagai ahli. Di antara penyelidikan yang telah beliau lakukan ialah Pembinaan Instrumen Amanah dan Kualiti Kerja Menurut al-Quran dan hadis, Kebolehpasaran Pelajar di KUIS, Kaedah Al-Quran Dalam Menangani Masalah Sosial: Kajian Di Pusat Perlindungan Majlis Agama Islam Selangor (MAIS) dan Pembinaan Model Psikologi Kominikasi Dalam Menanganai Konflik Rumahtangga Bermadu Menurut Perspektif Islam. Selain itu beliau juga aktif menyampaikan kuliah-kuliah tafsir di masjid dan surau. Beliau boleh dihubungi di emel sahlawati@kuis.edu.my 